\title{
Growth Performance of Rice in West Bengal Agriculture: A Spatio temporal Analysis
}

\author{
Arghyadeep Das ${ }^{1}$ and Sanjay Kumar ${ }^{2}$ \\ ${ }^{1}$ Division of Economics Statistics and Management, NDRI, Karnal- 132001, Haryana, India \\ ${ }^{2}$ Senior Agricultural Economist, Punjab Agricultural University, Ludhiana- 141004, Punjab, India \\ "Corresponding author: dasarghyadeep198@gmail.com
}

\begin{abstract}
The present study was conducted to analyze the rice cultivation scenario in West Bengal from 1994-95 to 2015-16. The study was based on secondary data collected from various sources. Study showed that production, yield, area under high yielding variety (HYV) and area under irrigation had a positive and significant growth rate, whereas area had negative and significant growth rate in overall period i.e., period III (1994-16). North 24 parganas, Cooch behar, Jalpaiguri showed highest growth rate in terms of area, production and yield respectively in period III. Among the traditional rice growing districts Midnapore showed higher growth rate in terms of production and yield than Bardhaman in period III. Midnapore and Bardhaman were among the top three districts in terms of area and production. Variable like rainfall (R) had negative and significant effect in growth of area and production showing unpredictability of monsoon caused the farmers to show reluctance in rice cultivation. Other variable like literacy rate (LR) and fertilizer consumption (FC) had positive and significant effect on growth rate of yield and gross irrigated area (GIA) in terms of growth of area under rice cultivation.
\end{abstract}

Keywords: West Bengal, agriculture, growth, performance, production, yield, rice

Rice occupies about 24 per cent of total cropped area of the country. Rice is the major component of food grain and cereal in the country contributes 43 per cent and 46 per cent of the total food grain and cereals respectively. India accounts for 22 per cent of total world's rice production. In Eastern and southern part of the country rice is considered as staple food. Most outstanding states in India for the production of rice were West Bengal (13.91 per cent), Andhra Pradesh (6.85 per cent), Uttar Pradesh (11.53 per cent), Punjab (10.53 per cent), Odisha (7.87 per cent), Tamil Nadu (5.43 per cent), Chhattisgarh (5.99 per cent), Bihar (6.02 per cent), Karnataka (3.36 per cent) and Haryana (3.80 per cent) during the period 2014-15 (Anonymous, 2016). The area under rice was found to be 44 million hectares in 2014-15 crop year occupying about 24 percent of total cropped area of the country. Due to severe drought India's rice production declined from record 99.18 million tonnes in the year 2008-09 to 89.13 million tonnes during 2009-10 but again gained its momentum and reached to a record high of 104.4 MT during the period 2015-16 (Anonymous, 2016).

Livelihood of 65 per cent of the population who live in the village is based on agriculture in West Bengal. Contribution of agriculture about 20.69 per cent to the total net State Domestic Product reflects significance of agriculture of this state. The state's net sown area is 61 per cent of total geographical area which is much higher than national average (46 per cent). Presently the gross cropped area of West Bengal is 97.5 lakh hectares with 184 per cent cropping intensity. About 80 per cent of the agricultural land is belonged to the marginal and small farmers who consists over 95 per cent of total farm population. West Bengal's agriculture is highly depended on monsoon and area under irrigation is 69 per cent which is much lower than other states (Anonymous, 2009). 
West Bengal is one of the important agricultural state in eastern Indian in spite of having only 2.78 per cent of total country's cultivable area. In West Bengal, the production of rice was 14.80 million tonnes during the period 2014-15, which was about 14.03 Percent of the country production, which was the major contribution (Anonymous, 2016). Rice covered almost 55.63 per cent of the total cropped area of the state during 2014-15 (Anonymous, 2016). The area and production under food grains during 2014-15 were 62.76 lakh hectare and 177.63 lakh metric tonnes respectively, out of which 88 per cent of total area and 90 per cent of total production was comprised by rice (Anonymous, 2016).

\section{Database and Methodology}

The study was undertaken on a macro framework based on secondary data in Punjab. To meet the objectives of this study, data on different variables such as area, production and yield of rice of selected two states were collected from India stat.com and statistical abstracts of the respective states. Farm level data on input uses and their respective prices and also farm harvest price of paddy from 1994-95 to 2013-14 were collected from the "Comprehensive Scheme for the Study of Cost of Cultivation of Principal Crops", Directorate of Economic and Statistics, for the rice produced in selected states.

Compound Annual Growth Rate (CAGR) of area, production and productivity were worked out to evaluate the performance of rice crop district wise for both states. The period was divided into three parts period I (1994-04) period II (2004-16) and overall period i.e., period III (1994-16). Period I was broadly corresponded to the period of turbulence in the economy characterized by dwindling of public expenditure in agriculture. Period II was characterized by sharp reversal of the public investment and agricultural performance.

\section{Merging of districts}

For feasible comparison it was necessary to merge some districts to its parent districts for both states. Merging was based on the ratio of net sown area which were extracted from its parent districts and depicted in the following table as following coefficients:

\begin{tabular}{cccc}
\hline $\begin{array}{c}\text { Sl. } \\
\text { No. }\end{array}$ & New districts & $\begin{array}{c}\text { Old } \\
\text { districts }\end{array}$ & $\begin{array}{c}\text { Coefficient of merging } \\
\text { of new districts with its } \\
\text { parent districts }\end{array}$ \\
\hline 1 & $\begin{array}{c}\text { East } \\
\text { Midnapore } \\
\text { West }\end{array}$ & 0.50 \\
& Midnapore & 0.50 \\
& Midnapore & \\
\hline 2 & North Dinajpur & Dinajpur & 0.50 \\
& South Dinajpur & 0.50 \\
\hline
\end{tabular}

\section{Growth analysis}

The compound annual growth rates (CAGR's) of area, production, yield, partial factor productivity and total factor productivity of rice and its input growth pattern were estimated for West Bengal and Punjab states by using semi log form of the exponential growth function.

The growth model used is as under:

$$
Y_{\mathrm{t}}=A B^{\mathrm{t}}
$$

Where,

$Y_{\mathrm{t}}=$ Area/production/productivity of rice for the year ' $t$ '.

$\mathrm{t}=$ Time variable $(1,2 \ldots \ldots ., \mathrm{n})$ for each period.

$\mathrm{A}=$ Constant

$B=$ Growth coefficient

Log transformation of above function is:

$$
\ln \mathrm{Y}_{\mathrm{t}}=\ln \mathrm{A}+\mathrm{t}(\ln \mathrm{B}) .
$$

Where,

$$
\begin{aligned}
& \ln B=\ln (1+r), \text { and } \\
& t=[\operatorname{antilog}(\ln B)-1] \\
& \text { CAGR's }(\text { per cent })=[\operatorname{antilog}(\ln B)-1] \times 100
\end{aligned}
$$

Student's-test was used to test the test the significance CAGR.

\section{Determinants of Growth Rate in Area, Production and Yield}

This study has examined the determinants of growth in area, production and yield in rice at the state level through neo-classical growth model and aggregate growth model can be specified as equation (1):

$$
\mathrm{Y}=\mathrm{f}(\mathrm{R}, \mathrm{LR}, \mathrm{CI}, \mathrm{GCA}, \mathrm{GIA}, \mathrm{FC})
$$




\begin{tabular}{lcl}
\hline Variables & Notations & Method of measurement \\
\hline Growth rates in area, production and yield & Y & Annual compound growth rates of area, production and yield \\
Rainfall & R & Actual rainfall as the ratio to normal rainfall \\
Literacy rate & LR & Literacy rate \\
Cropping intensity & CI & The ratio of gross cultivable area to net cropped area \\
Gross cultivable area & GCA & Gross rice cropped area as a ratio to the total gross cropped area \\
Gross irrigated area & GIA & Gross irrigated area of rice as a ratio of total gross irrigated area. \\
Fertilizer consumption & FC & $\begin{array}{l}\text { Total fertilizer consumed for crop production as a ratio to the gross } \\
\text { cropped area. }\end{array}$ \\
\hline
\end{tabular}

The growth rates in area, production and yield generally determine the overall performance of an agarian economy and are treated as dependent variables in a broad analytical framework (Bhattacharya and Bhattacharya, 2007). The consumption of fertilizers and cropping intensity are taken as the main technological variables. The rationale for including rainfall in the production function is that a significant proportion of cultivated area depends on rainfall and its variation affects the crop output substantially. Similarly, as the gross cultivated area had shown very little fluctuation over time, it had been taken as proxy for available land for cultivation. The gross irrigated area represents water-use from all the sources of irrigation for crop production. Education had a significant impact on agricultural productivity through refining the quality of labour, and increasing the acess to information and awareness programmes on agricultural practices. Thus, literacy rate had been considered as an important variable in the study. Not withstanding the limitations, the selected variables do have a good capacity to present the true picture of overall agricultural performance of the state.

\section{RESULTS AND DISCUSSION}

From Table 1, it is clear that during period I (199404) growth of production (2.35 per cent) was due to growth in yield (2.29 per cent) because growth of area was almost stagnant at that time (0.011 per cent). But during period II (2004-16) stagnation

Table 1: Compound annual growth rate of area, production and yield of rice in West Bengal (per cent per annum)

\begin{tabular}{cccccc}
\hline Year & Area & Production & Yield & Area under HYV & Area under irrigation \\
\hline Period I (1994-04) & $0.011(0.004)$ & $2.35^{* *}(0.006)$ & $2.29^{* * *}(0.003)$ & $4.38^{* * *}(0.008)$ & $7.41^{* *}(0.023)$ \\
Period II (2004-16) & $-0.72^{*}(0.0035)$ & $0.38(0.003)$ & $1.25^{* * *}(0.002)$ & $-0.54^{*}(0.003)$ & $0.23(0.006)$ \\
Period III (1994-16) & $-0.48^{* * *}(0.001)$ & $1.06^{* * *}(0.002)$ & $1.44^{* * *}(0.001)$ & $1.09^{*}(0.003)$ & $1.95^{* *}(0.007)$ \\
\hline
\end{tabular}

Note: ${ }^{* * *}$ significant at 1 per cent level, ** significant at 5 per cent level, * significant at 10 per cent level.

Figures in the parenthesis are standard errors.

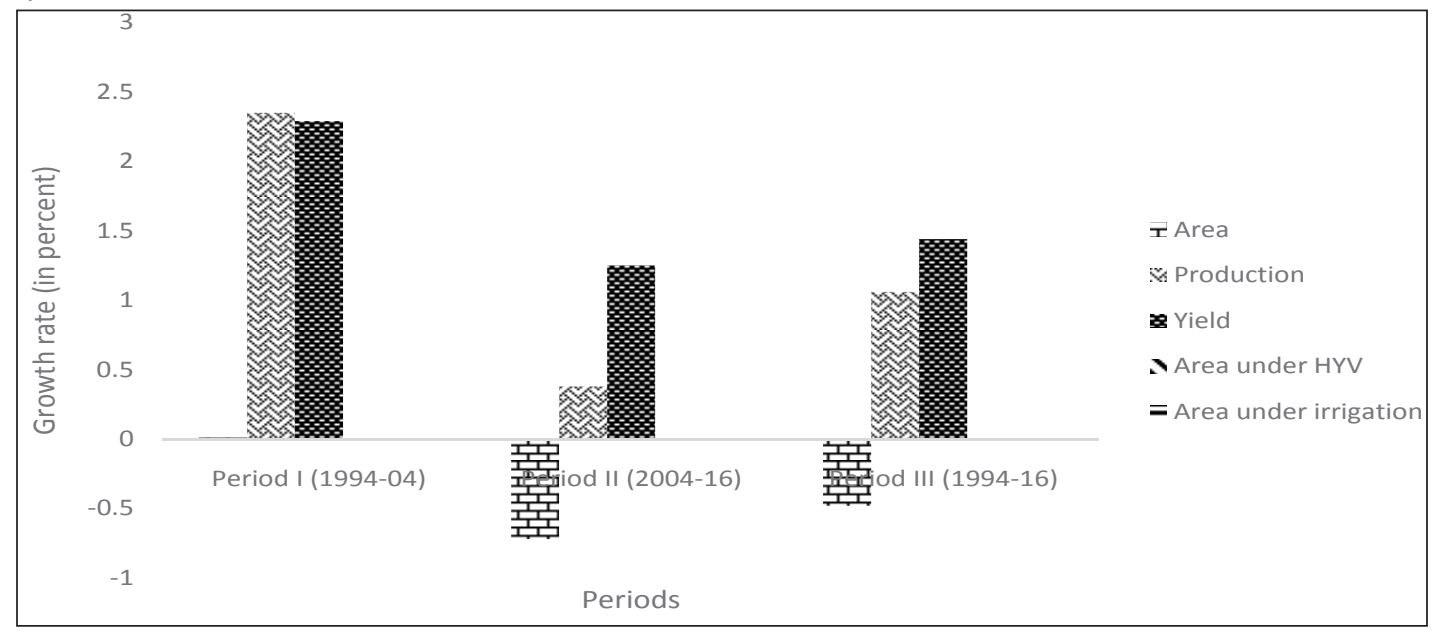

Fig. 1: Compound annual growth rate of area, production, yield, area under HYV and area under irrigation of rice in West Bengal 
of production (0.38 per cent) was solely due to declination of area ( -0.72 per cent). In period III (1994-16) growth of production was mainly effected by growth in yield (1.44 per cent) (Fig. 1). The occurrence of massive growth might be because of the sharp increase of area under irrigation due to 'Accelerated Irrigation Benefit Programme' (Fig. 1). However during period II (1994-16) the growth rate became stagnant bearing 0.23 percent only. CAGR of area under HYV increased during period I but in period II it decreased.

\section{District wise rice cultivation scenario}

The temporal changes of area, production and yield across different districts of West Bengal is furnished in Table 2. Again for the convenience of the study the overall periods have been divided in three parts, Period I (1994-04), Period II (2004-15) and Period III (1994-15).

The districts of Gangetic plain have the advantage of fertile loam and sandy loam soil and clear edge of having both surface and sub-soil irrigation over other regions of the state. It is suitable for paddy cultivation. Bardhaman, Howrah, Hooghly, Nadia, Malda, Murshidabad and Midnapore come under this agro-climatic zone.

The data presented in the table depicts that in Bardhaman and Hooghly the yield of rice remained stable despite of significant reduction in area during period II. The production went down in Period II might be due to reduction of area of that same period. A sharp increase in production and productivity could be seen in case of Midnapore despite of significant decrease in area in the period I scenario was same for Malda only growth rate of production during the first period was lower than Midnapore. Rice production and productivity in Nadia and Murshidabad showed a tremendous increase regardless of relatively short expansion of area in period I. Growth rate of production during period II decreased because of acute fall of area at that time it even went to negative in case

Table 2: Compound annual growth rate of area, production, yield of rice across different districts of West Bengal (per cent per annum)

\begin{tabular}{|c|c|c|c|c|c|c|c|c|c|}
\hline & \multicolumn{3}{|c|}{ Period I (1994-04) } & \multicolumn{3}{|c|}{ Period II (2004-15) } & \multicolumn{3}{|c|}{ Period III (1994-15) } \\
\hline & A & $\mathbf{P}$ & $Y$ & A & $\mathbf{P}$ & $\mathrm{Y}$ & A & $\mathbf{P}$ & $Y$ \\
\hline $\begin{array}{c}\text { Bardha- } \\
\text { man }\end{array}$ & $0.58(0.006)$ & $1.41(0.01)$ & $0.82(0.005)$ & $-1.08^{* *}(0.004)$ & $-0.19 *(0.006)$ & $0.90^{*}(0.004)$ & $-0.34(0.002)$ & $0.33(0.003)$ & $0.67^{* * *}(0.002)$ \\
\hline Midnapore & $-1.11^{*}(0.005)$ & $2.07^{*}(0.007)$ & $3.22^{* * *}(0.007)$ & $0.35(0.003)$ & $1.10(0.006)$ & $0.74(0.005)$ & $0.21(0.002)$ & $1.51^{* * *}(0.002)$ & $1.29^{* * *}(0.003)$ \\
\hline Nadia & $0.97(0.01)$ & $3.05^{* *}(0.01)$ & $2.07^{* * *}(0.005)$ & $-1.38^{* *}(0.005)$ & $0.04(0.007)$ & $1.44^{* * *}(0.003)$ & $\begin{array}{c}-1.40^{* * *} \\
(0.004)\end{array}$ & $-0.38(0.004)$ & $1.03^{* * *}(0.002)$ \\
\hline Malda & $-1.86(0.01)$ & $0.28(0.006)$ & $2.39^{* * *}(0.006)$ & $0.69(0.014)$ & $1.96(0.012)$ & $1.25^{* *}(0.006)$ & $-1.36^{* *}(0.005)$ & $1.28^{* * *}(0.003)$ & $2.46^{* * *}(0.002)$ \\
\hline Hooghly & $0.14(0.016)$ & $0.88(0.017)$ & $0.74(0.005)$ & $-1.17^{* * *}(0.002)$ & $-0.41(0.004)$ & $0.77^{* *}(0.003)$ & $0.082(0.003)$ & $1.16^{* * *}(0.004)$ & $1.08^{* * *}(0.001)$ \\
\hline Howrah & $1.36(0.006)$ & $5.18^{* * *}(0.012)$ & $3.77^{* * *}(0.009)$ & $-1.39^{* * *}(0.004)$ & $0.62(0.017)$ & $2.04(0.014)$ & $-0.53^{* *}(0.002)$ & $1.00(0.006)$ & $1.55^{* * *}(0.004)$ \\
\hline Birbhum & $0.57(0.009)$ & $3.64^{* *}(0.014)$ & $3.06^{* * *}(0.009)$ & $-0.45(0.013)$ & $0.29(0.015)$ & $0.71(0.006)$ & $-0.13(0.004)$ & $1.28^{* *}(0.005)$ & $1.41^{* * *}(0.003)$ \\
\hline $\begin{array}{l}\text { South } 24 \\
\text { Parganas }\end{array}$ & $0.23(0.003)$ & $4.03^{* *}(0.01)$ & $3.37^{* *}(0.01)$ & $-0.43^{*}(0.003)$ & $1.23^{*}(0.006)$ & $1.66^{* * *}(0.005)$ & $\begin{array}{c}-0.77^{* * *} \\
(0.001)\end{array}$ & $1.17^{* * *}(0.003)$ & $2.01^{* * *}(0.002)$ \\
\hline Dinajpur & $1.60^{* *}(0.006)$ & $3.62^{* * *}(0.007)$ & $1.99 *(0.009)$ & $-2.10^{* * *}(0.004)$ & $-0.71(0.006)$ & $1.42^{* *}(0.005)$ & $-0.65^{* *}(0.003)$ & $1.27^{* * *}(0.003)$ & $1.93^{* * *}(0.002)$ \\
\hline Jalpaiguri & $0.58(0.004)$ & $5.35^{* * *}(0.009)$ & $5.00^{* * *}(0.008)$ & $-0.81^{* *}(0.002)$ & $4.13^{* * *}(0.005)$ & $4.98^{* * *}(0.006)$ & $\begin{array}{l}-0.62^{* * *} \\
(0.001)\end{array}$ & $3.05^{* * *}(0.003)$ & $3.81^{* * *}(0.003)$ \\
\hline $\begin{array}{l}\text { Cooch } \\
\text { Behar }\end{array}$ & $\begin{array}{c}-0.39 \\
(0.004)\end{array}$ & $\begin{array}{l}4.28^{* * *} \\
(0.008)\end{array}$ & $\begin{array}{l}4.70^{* * *} \\
(0.006)\end{array}$ & $\begin{array}{c}0.21 \\
(0.006)\end{array}$ & $\begin{array}{l}4.69^{* * *} \\
(0.007)\end{array}$ & $\begin{array}{l}4.47^{* * *} \\
(0.009)\end{array}$ & $\begin{array}{c}-0.20 \\
(0.002)\end{array}$ & $\begin{array}{l}3.39^{* * *} \\
(0.003)\end{array}$ & $\begin{array}{l}3.60^{* * *} \\
(0.003)\end{array}$ \\
\hline Darjeeling & $-1.77^{* *}(0.006)$ & $2.68(0.022)$ & $4.29^{* *}(0.015)$ & $-0.48(0.003)$ & $3.26^{* * *}(0.009)$ & $3.77^{* * *}(0.01)$ & $\begin{array}{c}-1.14^{* * *} \\
(0.001)\end{array}$ & $2.51^{* * *}(0.005)$ & $3.57^{* * *}(0.004)$ \\
\hline
\end{tabular}

$\overline{* * *}$ significant at 1 per cent level, ${ }^{* *}$ significant at 5 per cent level, * significant at 10 per cent level; Figures in the parenthesis are standard errors. 
Murshidabad, although the growth rate of yield was quiet significant. Howrah was historically been a district with more industrial enterprises than agriculture. District's proximity to Kolkata metropolitan city gives it a locational advantage for such industrial development. In such a district it is interesting to see a definite increase in compound annual growth rate (CAGR) of area, production and yield during the period I. During period II the growth rate production went down due to severe fall in area, but still the yield showed notable growth rate.

Agro-climatic specificities in the Red and laterite region are entirely different from the situation in the alluvial plain. The soil is mostly sandy to sandyloam. Water retention capacity is rather poor. During period I Birbhum and Purulia showed outstanding growth rate in production and yield. The area of Bankura and Purulia during period I went down sharply. Reduction in area might be the reason for the negative growth rate of production in Bankura during that time. The formidable performance of these districts were short lived. During the period II growth rate of production for both Bankura and Purulia turned into negative however Birbhum somehow managed to secure its growth rate in positive value. The growth rate of area for all these three districts were negative with meagre growth rate of yield during period II.

In West Bengal the coastal districts suffer from problems of soil salinity and sippage of saline water from Bay-of-Bengal. North and South 24 Parganas are the two districts having coastal proximity. During Period I the performance of South 24 Parganas was far better than North 24 Parganas in terms of growth of production and yield. During period II CAGR of production of North 24 Pargans fell due to even more down fall of the CAGR of the area, CAGR of production of South 24 Parganas also came down might be for the same reason. However during two consecutive time periods the growth rate of yield for the two districts were notable.

Coming to the specificities of Terai region, the districts receive heavy to moderate rainfall during monsoon. Water retention in the soil is moderate. But there remains residual moisture during rabi season. Soil quality is mostly sandy. There is no proper mechanism of rain-water harvesting. Hence, rain-water gets lost as run-off into the rivers
Tista and Mahananda. Kharif Paddy remains the main crop. Dinajpur, Jalpaiguri and Cooch Behar demonstrate such geo-morphological pattern. All the three districts showed excellent increase in growth rate of production and yield for both periods, but negative growth rate area in Dinajpur during the period II pulled down the CAGR of production at the same period.

In Hilly tracts of Darjeeling Tea and Timber are the main products. There are horticultural crops too. But Terrace cultivation of Rice here is somewhat secondary in this district. Over the years the CAGR of area of Rice in Darjeeling was negative. Production and Productivity reflected huge increment in both periods.

\section{Percentage share of area and production under rice in districts}

Results in the (Fig. 2) shows that seven major rice growing districts of West Bengal comprised almost 64 per cent area of total cultivated area. Midnapore had the highest area under rice cultivation (20.34 per cent), followed by Bardhaman (10.80 per cent), Dinajpur (7.37 per cent), South 24 Parganas (7.07 per cent), Birbhum (6.92 per cent), Bankura (6.73 per cent), Murshidabad (6.49 per cent).

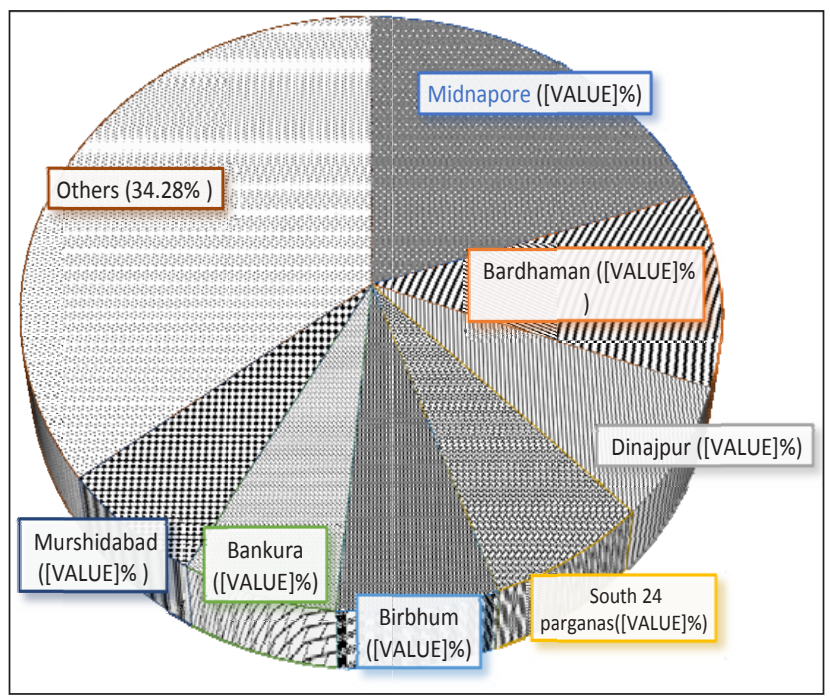

Fig. 2: Area under rice in important districts of West Bengal

In terms of production, seven major rice producing districts consists 65 per cent of the total State's rice production (Fig 3). Among those districts Midnapore again ranked top with (18.84 per cent), followed by Bardhaman (12.62 per cent), Birbhum (7.83 per cent), Murshidabad (7.09 per cent), 
Dinajpore (7.08 per cent), Bankura ( 6.62 per cent) and South 24 Parganas (6.30 per cent).

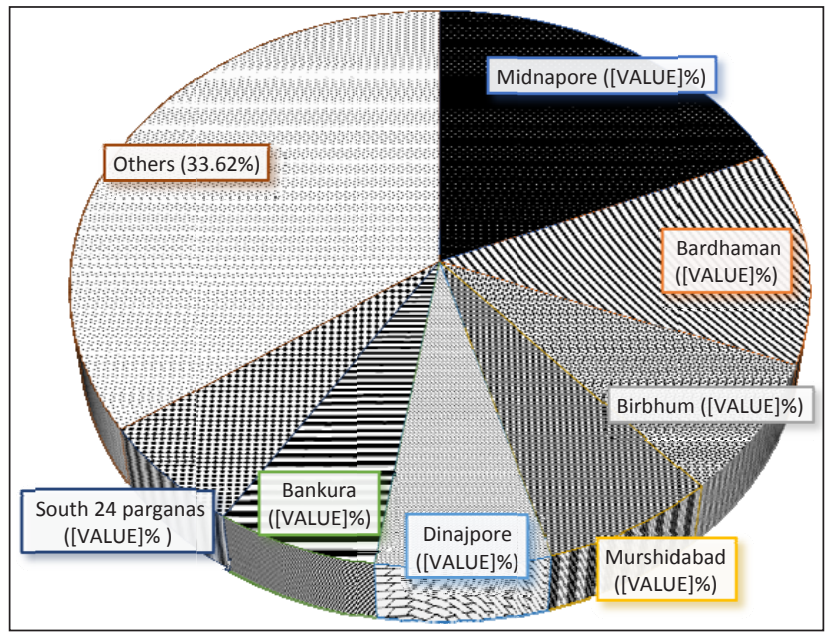

Fig. 3: Production under rice in important districts of West Bengal

\section{Factor affecting growth in area, production and yield of rice in West Bengal}

The result regarding the effect of factors on growth of area, production and yield of West Bengal are presented in Table 3. In case of area coefficient of cropping intensity, gross cultivable area, gross irrigated were positive and significant where coefficient of rainfall and fertilizer consumption were negative and significant, this might be due to unpredictability of monsoon caused the farmers to show reluctance in rice cultivation. and negative effect of fertilizer consumption was due to same reason. In terms of production cropping intensity and gross cultivable area were positive and significant, but coefficient of rainfall again were negative and significant, this may be due to poor distribution of rainfall in recent years turned down the production of rice. In case of yield coefficient of literacy, cropping intensity and fertilizer consumption were both positive and significant. It was notable that coefficient of literacy were significant and positive effect on yield that means rural literacy help the educated rural youth to remain in agriculture and contribute their knowledge for the efficient use of inputs which will result in increase in yield of rice throughout the studied period. Pattanaik and Mohanty (2016) while studying factor affecting growth rate in area, production and yield of Odisha agriculture during 1993-94 to 2003-04 and 2003-04 to 2010-11 also had found same positive and significant effect of gross cultivable area and gross irrigated area to area, production and yield of Odisha agriculture.

\section{CONCLUSION}

During period I (1994-04) growth of production (2.35 per cent) was due to growth in yield (2.29 per cent) because growth of area was almost stagnant at that time (0.011 per cent). The occurrence of massive growth during period II might be because of the sharp increase of area under irrigation due to 'Accelerated Irrigation Benefit Program'. CAGR

Table 3: Factors affecting growth in area, production and yield of rice in West Bengal from 1994-95 to 2015-16

\begin{tabular}{cccc}
\hline Variables & Area & Production & Yield \\
\hline Rainfall (R) & $-0.032^{*}(-1.71)$ & $-0.138^{* *}(-2.63)$ & $-0.011(-0.23)$ \\
Literacy Rate (LR) & $-0.021(-0.29)$ & $0.268(1.35)$ & $0.278^{*}(1.72)$ \\
Cropping Intensity (CI) & $1.06^{* * *}(9.38)$ & $1.75^{* * *}(5.51)$ & $0.562^{* *}(1.85)$ \\
Gross cultivable area (GCA) & $1.42^{* * *}(8.45)$ & $1.09^{* *}(2.30)$ & $-0.294(-0.65)$ \\
Gross irrigated area (GIA) & $0.069^{* * *}(3.14)$ & $0.062(1.00)$ & $-0.003(-0.05)$ \\
Fertilizer consumption (CI) & $-0.058^{* * *}(-2.68)$ & $-0.034(-0.56)$ & $0.084^{*}(1.72)$ \\
Constant & $4.57^{* * *}(7.89)$ & $1.45(0.89)$ & $3.32^{* *}(2.14)$ \\
F-stat & 70.12 & 27.19 & 38.32 \\
R-squared & 0.965 & 0.916 & 0.939 \\
Adj. R-squared & 0.951 & 0.882 & 0.914 \\
No. of observations & 22 & 22 & 22 \\
\hline
\end{tabular}

Source: India stat.com 2016.

Note: *** significant at 1 per cent level, ${ }^{* *}$ significant at 5 per cent level, * significant at 10 per cent level.

The figures within the parentheses are the value of $t$-statistics. 
of area under HYV increased during period I but in period II it decreased.

In West Bengal Bardhaman, Birbhum and Midnapore area three major rice producing districts, during period I (1994-04) all the three districts showed positive growth rate in terms of production and yield and only Midnapore showed negative growth rate in area. Darjeeling, Cooch bihar, Jalpaiguri showed tremendous growth rate production and yield. During period II (2004-15) due to fall in area many districts displayed negative growth rate in production. Midnapore and Bardhaman are the two top most ranking districts in terms of both area and production.In West Bengal coefficient of cropping intensity, gross cultivable area, gross irrigated area and fertilizer consumption were positive and significant where coefficient of rainfall were negative and significant in growth of area under rice cultivation. In terms of production cropping intensity and gross cultivable area were positive and significant, but coefficient of rainfall again were negative and significant. In case of yield coefficient of literacy, cropping intensity and fertilizer consumption were both positive and significant.

\section{REFERENCES}

Anonymous 2009. Statistical Hand Book of West Bengal, Department of Statistics and Program Implementation, Government of West Bengal.

Anonymous 2016. Area and Production under Rice in India Retrieved from www.indiastat.com.Anonymous (2016) Area and Production under Rice in West Bengal Retrieved from www.indiastat.com.

Bhattacharya, S. and Bhattacharya, M. 2007. Agarian impasse in West Bengal in the liberalisation era. Economic and Political Weekly, 42(52): 65-71.

Pattanaik, F. and Mohanty, S. 2016. Growth Performance of Major Crop Groups in Odisha Agriculture: A Spatiotemporal Analysis. Agricultural Economic Research Review. 29: 225-37. 
